\title{
Liquid limit of selected postglacial soils from west-central Poland
}

\author{
Dorota KRAWCZYK ${ }^{1, *}$, Michalina FLIEGER-SZYMAŃSKA ${ }^{1}$ and Dariusz WANATOWSKI ${ }^{2}$ \\ 1 Poznań University of Technology, Faculty of Civil and Environmental Engineering, Institute of Civil Engineering, Piotrowo \\ 5, 61-138, Poznań, Poland \\ 2 University of Leeds, Faculty of Engineering, School of Civil Engineering, Leeds LS2 9JT, United Kingdom
}

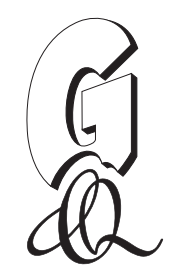

Krawczyk, D., Flieger-Szymańska, M., Wanatowski, D., 2019. Liquid limit of selected postglacial soils from west-central Poland. Geological Quarterly, 63 (4): 711-720, doi: 10.7306/gq.1497

Associate Editor: Beata Jaworska-Szulc

The aim of this paper is to establish a correlation between the liquid limit value obtained in the Casagrande apparatus ( $\mathrm{w}_{\mathrm{L} / \mathrm{cup}}$ ) and in the cone penetrometer ( $\left.\mathrm{w}_{\mathrm{L} / \mathrm{cone}}\right)$ for typical glacial sediments from west-central Poland and compare them with the correlation equations published in the literature. The following correlation was formulated: $\mathrm{w}_{\mathrm{L} / \text { cone }}=0.91 \mathrm{w}_{\mathrm{L} / \mathrm{cup}}+1.98$. The analysis presented in this paper proves that deriving a generalized and universal relationship $\mathrm{W}_{L / \mathrm{cup}} / \mathrm{W}_{\mathrm{L} / \mathrm{cone}}$ for all cohesive soils, regardless of their origin, is very challenging and may not be reliable for use in the engineering practice. It is verified that, in the range of low values of liquid limit, the cone penetrometer gives higher values of $W_{L}$ than those obtained from the Casagrande apparatus. However, for the Polish postglacial soils analysed in this paper, the cone penetrometer underestimates the results in relation to the Casagrande apparatus above $\mathrm{w}_{\mathrm{L}}=22 \%$. For the purpose of this study, $\mathrm{w}_{\mathrm{L}}=22 \% \mathrm{was}$ defined as "the point of equivalent results" ( $\left.\mathrm{w}_{\mathrm{L} / \text { cone }}=\mathrm{w}_{\mathrm{L} / \text { cup }}\right)$.

Key words: liquid limit, tills, varved clays, cone penetrometer, Casagrande apparatus.

\section{INTRODUCTION}

The concept of consistency limits used to classify finegrained soils was introduced at the beginning of the 20th century by Swedish scientist Albert Mauritz Atterberg (1911, 1912). At present, the so-called liquid limit - $\mathrm{w}_{\mathrm{L}}$ (a soil moisture content situated exactly between the liquid and plastic consistencies) and the so-called plastic limit $-w_{p}$ (separating the plastic and semi-solid states) are among the basic geotechnical parameters determining the range of moisture content in which the soil retains its plastic properties. In the traditional view, the accurate measurement of Atterberg limits is an important issue of engineering geology.

Using $\mathrm{w}_{\mathrm{L}}, \mathrm{W}_{\mathrm{P}}$ values and the natural moisture content of soil, the liquidity index $\left(\mathrm{I}_{\mathrm{L}}\right)$, can be calculated. It is the main parameter used to define the physical state of cohesive soils. The state of cohesive soil determines the load-bearing capacity of the soil, so the value of $I_{L}$ is important for the design of foundations. In addition, in Polish engineering practice the value of the liquidity index is used to determine other geotechnical parameters by the so-called indirect method, i.e. based on the existing correla-

\footnotetext{
* Corresponding author, e-mail: dorota.krawczyk@put.poznan.pl Received: January 12, 2018; accepted: July 25, 2019; first published online: November 21, 2019
}

tions and not on laboratory tests. This method is commonly used for less complicated building structures which are founded in less complex ground and water conditions. For example, the indirect method can be used to determine bulk density $(\rho)$, undrained shear strength $\left(\mathrm{C}_{\mathrm{u}}\right)$, or oedometer compressibility modulus $\left(\mathrm{M}_{0}\right)(\mathrm{PN}-88 / \mathrm{B}-04481,1988)$.

Furthermore, the Atterberg limits are used to calculate the plasticity index of soil $\left(I_{P}\right)$. This parameter shows how much water soil absorbs when changing its consistency from solid to liquid, so it gives the range of moisture content in which the soil has plastic properties. Based on the value of plasticity index an approximate content of clay fraction in a given soil can be determined. Therefore, the $I_{p}$ describes the type and degree of cohesiveness of the sediment.

The consistency limits are also used to determine the susceptibility of cohesive soils to volume change behaviour (i.e. volumetric shrinkage and swelling).

There are two main laboratory methods for determining the liquid limit: the Casagrande apparatus method and the cone penetrometer (fall cone) method.

Atterberg defined the liquid limit as the moisture content above which the ground behaves like a liquid, it starts to flow and does not keep a given shape (Atterberg, 1911, 1912). Casagrande proposed a research method that would literally correspond to this original definition of the liquid limit (Casagrande, 1932). The apparatus designed by him is, therefore, the only tool that allows determining the $w_{\mathrm{L}}$ value approximate to its actual meaning. Nevertheless, it should be mentioned that the testing procedure for the Casagrande apparatus 
has many disadvantages (Sowers et al., 1960; Hanks, 1981), among others:

- the need to subjectively estimate the moment in which the groove has closed over an appropriate length, required by a given standard;

- various lengths of groove closing according to different standards (e.g., Polish PN-88/B-04481, 1988 and German Standard DIN 18122, 2008 - 10.0 mm, American ASTM D 4318, 2000 and British Standard BS 1377, 1990 - 13.0 mm, Czech Standard ČSN 721014, 1968 - 12.5 mm);

- the problem with cutting off the ideal groove (Wires, 1984; Spagnoli, 2012; especially in slightly plastic soils);

- the variable rate of hitting the cup in hand-operated apparatus;

- the problem with the even spreading of the soil paste in the bowl (in particular, the problem with maintaining the same thickness of the paste over the entire sample);

- the lack of duplication of a single result;

- the time consumption of the test (an experienced operator needs $\sim 40 \%$ more time to complete the determination of the liquid limit in the Casagrande apparatus than in the cone penetrometer; Wires, 1984);

- various rubber bases used in different countries (dimensions of the base, e.g. according to the Polish standard, PN-88/04481, $1988-85 \times 50 \times 25 \mathrm{~mm}$, according to the American standard, ASTM D 4318, $2000-150 \times 125 \times$ $50 \mathrm{~mm}$, the hardness of the rubber from which the base is made and the difficulty in comparing it between instruments used in different countries - different hardness scales used in each national standard; Özer, 2009).

Furthermore, over the years of using the Casagrande apparatus, the device itself and the test procedure have undergone a number of minor, but still significant modifications, which, in general, have led to an increase of the liquid limit value (PKN-CEN ISO/TS 17892-12, 2009).

The procedure for determining the liquid limit in the cone penetrometer does not correspond to the original definition of this parameter, because the behaviour of the soil (plastic or liquid) is not the object of research. Besides, the main disadvantage of this procedure is the need to remove thoroughly thicker fractions from the soil paste. According to the European standard, grains larger than $0.04 \mathrm{~mm}$ should be removed (PKN-CEN ISO/TS 17892-12, 2009). First of all, this requirement is difficult to meet, and secondly, the removal of all mentioned grains substantially changes the soil structure. Therefore, the tests are carried out on a soil paste, which significantly differs in grain size from a sample of natural soil. It is assumed, however, that the clay fraction is responsible mainly for the properties of cohesive soils, in particular for the intensity of the soil skeleton-water interaction. An additional difficulty during cone penetrometer tests is the risk of enclosing the air bubbles inside the sample formed from soil paste. That may significantly disturb the process of the test (Fig. 1).

However, the cone penetrometer is widely used in many countries due to the less complicated testing procedure, higher repeatability of results and shorter time needed to carry out the test (Sridharan et al., 1999). The advantage of the fall cone test is its objectivity - the measurement of the cone penetration depth is carried out using a calliper, usually electronic. In addition, the test procedure assumes determining the depth of penetration as long as two consecutive results will be nearly identical (permissible difference is $0.4-0.5 \mathrm{~mm}$ depending on the type of cone; PKN-CEN ISO/TS 17892-12, 2009).
Several attempts can be found in the literature to correlate the results obtained with the Casagrande apparatus and the cone penetrometer (Wires, 1984; Budhu, 1985; Wasti, 1987; Christaras, 1991; Leroueil and Le Bihan, 1996; Suchnicka, 1999; Orhan et al., 2006; Dragoni et al., 2008; Özer, 2009; Fojtová et al., 2009; Grønbech et al., 2011; Spagnoli, 2012; Di Matteo, 2012; Jaśkiewicz and Wszędyrówny-Nast, 2013; Hrubesova et al., 2016), as shown in Table 1 and Figure 2. They concern both natural soils and man-made clay-silt-sand mixtures. Frequently, soils with the widest range of clay fraction content and with highly diversified $\mathrm{W}_{\mathrm{L}}$ values are included in the research. This procedure is necessary to establish the universal relationship between the liquid limit value determined in the cone penetrometer ( $\left.w_{L / c o n e}\right)$ and the liquid limit value determined in the Casagrande apparatus ( $\mathrm{w}_{\mathrm{L} / \mathrm{cup}}$ ), as shown in Table 1.

According to the authors, however, there is a need to derive this type of correlation at the local level. It is assumed that such a correlation would be more accurate and more useful for the engineering practice if the specific characteristics of a particular deposit in given subsoil are taken into account.

The research described in this paper has therefore a slightly different context. Natural clayey soils of known origin, strictly defined genetic features and accurately described in terms of granulometry, and mineralogy were analysed. Two types of glacigenic soils that differed significantly in terms of granulometry and mineral composition were selected.

The aim of the paper is to establish a correlation between the results obtained in the Casagrande apparatus and in the cone penetrometer for typical glacial sediments from west-central Poland and compare them with the correlation equations published in the literature. The results obtained in this way have a real chance to find application in the design of foundations not only in Poland but also in all areas where the genetically similar sediments of the youngest glaciation occur.

In many European countries, such as Poland, Germany (e.g., Spagnoli, 2012) or the Czech Republic (e.g., Fojtová et al., 2009), the Casagrande apparatus as a classic method, strongly rooted in engineering practice, is widely used for determining the $W_{L}$ value. Therefore, many results of scientific research and engineering case studies are based on the value of $\mathrm{w}_{\mathrm{L}}$ determined in this way. Currently, Eurocode 7 (PN-EN 1997-1/2 Eurokod 7, 2008/2009) recommends using the cone penetrometer as a faster and more precise method. Often enough there is a need to

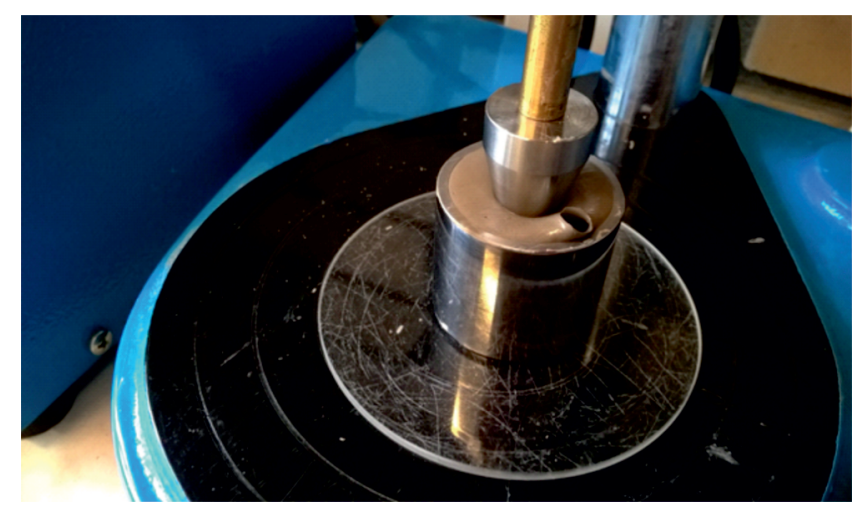

Fig. 1. The sample of varved clay in cone penetrometer (incorrect preparation of the sample - the air bubble closed inside the soil paste) 
Relationships between the liquid limit values determined in the Casagrande apparatus and in the cone penetrometer (according to different authors)

\begin{tabular}{|c|c|c|c|c|c|c|}
\hline Author (year) & Localization & $\begin{array}{l}\text { Type of studied } \\
\text { soil }\end{array}$ & $\begin{array}{l}\text { Numer of } \\
\text { samples }\end{array}$ & \begin{tabular}{|c|} 
Type of \\
Casagrande \\
apparatus \\
\end{tabular} & $\mathrm{w}_{\mathrm{L}}$ value & Correlation equation \\
\hline Karlsson $(1961,1977)$ & - & - & - & - & $30-76$ & $\mathrm{~W}_{\mathrm{L} / \text { cone }}=0.85 \mathrm{w}_{\mathrm{L} / \text { cup }}+5.02$ \\
\hline Littleton, Farmilo (1977) & - & - & - & soft base & - & $\mathrm{w}_{\mathrm{L} / \text { cone }}=0.97 \mathrm{w}_{\mathrm{L} / \text { cup }}+1.60$ \\
\hline Sherwood, Ryley (1970) & - & - & - & soft base & $30-72$ & $\mathrm{w}_{\mathrm{L} / \text { cone }}=0.95 \mathrm{w}_{\mathrm{L} / \text { cup }}+0.95$ \\
\hline Wires (1984) & - & $\begin{array}{l}\text { natural soils from } \\
\text { loam to heavy clay }\end{array}$ & 4 & hard base & $32-52$ & $\mathrm{~W}_{\mathrm{L} / \text { cone }}=0.94 \mathrm{~W}_{\mathrm{L} / \text { cup }}+0.97$ \\
\hline Belviso et al. (1985) & southern Italy & natural soils & 16 & hard base & $34-134$ & $\mathrm{w}_{\mathrm{L} / \text { cone }}=0.97 \mathrm{w}_{\mathrm{L} / \text { cup }}+1.19$ \\
\hline Budhu (1985) & Guyana & natural soils & 100 & soft base & $20-100$ & $\mathrm{w}_{\mathrm{L} / \text { cone }}=0.93 \mathrm{w}_{\mathrm{L} / \text { cup }}+4.30$ \\
\hline Sampson. Netterberg (1985) & South Africa & natural soils & - & hard base & - & $\mathrm{W}_{\mathrm{L} / \text { cone }}=1.01 \mathrm{~W}_{\mathrm{L} / \text { cup }}+4.20$ \\
\hline Queiroz de Carvalho (1986) & $\begin{array}{c}\text { north and } \\
\text { north-east Brazil }\end{array}$ & lateritic soils & 27 & soft base & $13-48$ & $\mathrm{~W}_{\mathrm{L} / \mathrm{cone}}=1.07 \mathrm{~W}_{\mathrm{L} / \mathrm{cup}}+2.18$ \\
\hline Wasti, Bezirci (1986) & Turkey & natural soils & 15 & hard base & $27-110$ & $\mathrm{~W}_{\mathrm{L} / \text { cone }}=1.01 \mathrm{~W}_{\mathrm{L} / \text { cup }}+4.92$ \\
\hline Leroueil, Le Bihan (1996) & eastern Canada & $\begin{array}{c}\text { marine silty clays. } \\
\text { lacustrine varved } \\
\text { clays }\end{array}$ & 44 & hard base & $30-74$ & $\mathrm{~W}_{\mathrm{L} / \text { cone }}=0.86 \mathrm{w}_{\mathrm{L} / \text { cup }}+6.34$ \\
\hline Sridharan et al. (1999) & - & $\begin{array}{l}\text { bentonite-sand } \\
\text { mixture and natural } \\
\text { soils }\end{array}$ & 15 & soft base & 29-92 & $\mathrm{w}_{\mathrm{L} / \text { cone }}=0.83 \mathrm{w}_{\mathrm{L} / \text { cup }}+10.80$ \\
\hline Sridharan, Prakash (2000) & - & $\begin{array}{l}\text { bentonite-sand } \\
\text { mixture }\end{array}$ & 16 & soft base & $33-92$ & $\mathrm{~W}_{\mathrm{L} / \text { cone }}=0.82 \mathrm{w}_{\mathrm{L} / \text { cup }}+9.95$ \\
\hline Orhan et al. (2006) & Turkey & natural soils & 16 & hard base & $27-98$ & $\mathrm{~W}_{\mathrm{L} / \text { cone }}=1.04 \mathrm{~W}_{\mathrm{L} / \text { cup }}+1.137$ \\
\hline Dragoni et al. (2008) & central Italy & natural clayey soils & 41 & hard base & $28-74$ & $\mathrm{w}_{\mathrm{L} / \text { cone }}=1.02 \mathrm{w}_{\mathrm{L} / \text { cup }}+2.87$ \\
\hline Özer (2009) & Turkey & natural soils & 32 & hard base & $29-104$ & $\mathrm{w}_{\mathrm{L} / \text { cone }}=0.90 \mathrm{w}_{\mathrm{L} / \text { cup }}+6.04$ \\
\hline Fojtová et al. (2009) & $\begin{array}{l}\text { Czech Republic } \\
\text { (Ostrava Basin) }\end{array}$ & $\begin{array}{c}\text { natural } \\
\text { fine-grained soils }\end{array}$ & 52 & hard base & $20-50$ & $\mathrm{w}_{\mathrm{L} / \text { cone }}=1.00 \mathrm{w}_{\mathrm{L} / \text { cup }}+2.44$ \\
\hline Grønbech et al. (2011) & Denmark & $\begin{array}{c}\text { Danish Eocene } \\
\text { clays } \\
\end{array}$ & 33 & hard base & $100-340$ & $\mathrm{~W}_{\mathrm{L} / \text { cone }}=0.95 \mathrm{~W}_{\mathrm{L} / \text { cup }}+9.40$ \\
\hline Di Matteo (2012) & $\begin{array}{l}\text { central Italy/various } \\
\text { places in Europe }\end{array}$ & $\begin{array}{c}\text { Holocene alluvial } \\
\text { deposits } \\
\text { mixtures/various } \\
\text { natural soils }\end{array}$ & 100 & hard base & $24-40$ & $\mathrm{~W}_{\mathrm{L} / \text { cone }}=1.00 \mathrm{~W}_{\mathrm{L} / \text { cup }}+2.20$ \\
\hline Spagnoli (2012) & $\begin{array}{l}\text { Baltic Sea } \\
\text { and North Sea }\end{array}$ & $\begin{array}{c}\text { pure non-swelling } \\
\text { clays } \\
\text { (kaolinite/illite } \\
\text { groups) }\end{array}$ & 50 & hard base & $28-61$ & $\mathrm{~W}_{\mathrm{L} / \text { cone }}=0.99 \mathrm{w}_{\mathrm{L} / \text { cup }}+1.05$ \\
\hline Present study & Great Poland & $\begin{array}{l}\text { tills and varved } \\
\text { clays of North } \\
\text { Polish Glaciation }\end{array}$ & 47 & hard base & $18-89$ & $\mathrm{~W}_{\mathrm{L} / \text { cone }}=0.91 \mathrm{~W}_{\mathrm{L} / \text { cup }}+1.98$ \\
\hline
\end{tabular}

compare the results obtained contemporarily with the existing database. The formulation of an amendment that would allow correcting the value of some geotechnical parameters based on the liquid limit value depending on the method of its determination could be the solution.

Experimental determination of such an amendment for glacial tills and varved clays of the youngest glaciation, which are typical deposits of the European Lowlands, is carried out.

It is to be hoped that this paper will provide the answers to the questions formulated below:

- is it possible to derive a generalized and universal relationship between the liquid limit value determined in the Casagrande apparatus ( $\mathrm{w}_{\mathrm{L} / \mathrm{cup}}$ ) and in the cone penetrometer ( $\left.\mathrm{w}_{\mathrm{L} / \mathrm{cone}}\right)$ for all cohesive soils, independently of origin? And if not, then...

- is it possible for soils with a similar genesis and mineral composition of clay fraction but a different grain size?

\section{TESTED SOILS AND TESTING METHODS}

In this study, 47 soil samples (from $7.5 \mathrm{~m}$ deep test boring) of the youngest glaciation soils occurring in the vicinity of Poznań (west Poland) were examined. These were glacial tills and varved clays (Fig. 3). The area of Poland was covered several times with a continental glacier. The last glaciation, called North Polish or Baltic Glaciation, has left many cohesive deposits on the surface (especially lodgement and melt-out tills) formed mainly as clayey sands (clSa) and a specific type of clays - varved clays. These clays are characterized by a specific structure with the alternating occurrence of light layers (sandy-silty or silty) and dark layers (silty-clay or clay) (Flieger-Szymańska and Machowiak, 2010). Engineering properties of cohesive soils, including the liquid limit, depend, among other factors, on the mineral composition of clay fraction (Florkiewicz 


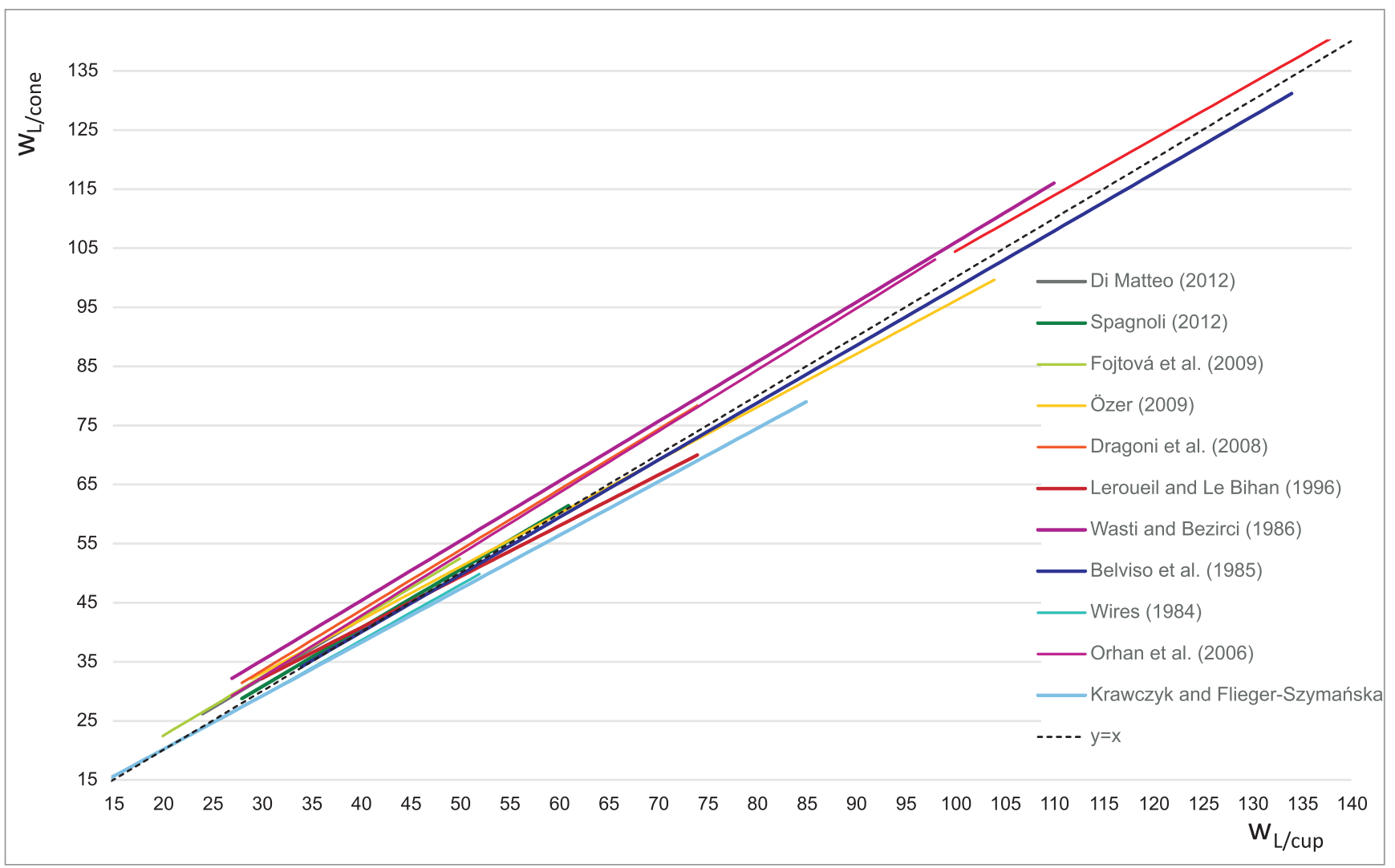

Fig. 2. Relationships between the liquid limit values determined in the Casagrande apparatus and in the cone penetrometer (according to different authors)

et al., 2015). For this reason, the qualitative determination of the mineral composition of clay fraction with the X-ray method was also carried out for the tested soil samples.

Diffraction patterns (Fig. 4) determined separately for the light and dark layers of varved clays show that, in the vertical profile within the clay fraction, there are no changes in the mineral composition in the light and dark layers. The main clay minerals are hydromicas (illites), kaolinite and smectite/chlorite. On the other hand, there is a clear difference in the content of quartz. In the light layers there is much more quartz than in the dark ones. The main clay minerals of the studied glacial tills are illite, kaolinite and smectite/illite mixed-layer minerals (Fig. 5). In addition, the finest fraction contains quartz, calcite, dolomite and plagioclase (Fig. 5). Therefore, it can be concluded that there is no significant difference in the mineral composition of clay fraction between both examined types of soils.

Laboratory testing carried out in the current study included macroscopic analysis of soil samples, determination of natural moisture content, grain-size analysis using both hydrometer and sieve methods, and determination of the plastic limit and liquid limit in the cone penetrometer with a $30 \% / 80 \mathrm{~g}$ cone and in the Casagrande apparatus with the so-called hard base (PN-88/B-04481, 1988; PKN-CEN ISO/TS 17892-1, 4, 12, 2009). It needs to be pointed out that the hardness of the rubber from which the Casagrande apparatus base is made significantly influences the liquid limit value (Norman, 1958; Özer, 2009). The softer the material from which the base is made, the higher the $w_{L}$ value. This principle is logical, because the soft rubber absorbs more energy of the cup impact than the hard one. Thus, in the tests carried out in the Casagrande apparatus with the soft base, more impact is needed to close the groove - this will happen at the 25th hit for the soil paste.

In practice, the Casagrande apparatus with the so-called "hard" base, i.e. with a hardness similar to that described in the American standard ASTM D 4318, 2000, is used more often (outside the United States this type of apparatus is widely used in Canada and in the continental part of Europe). The Casagrande apparatus, described in the British Standard BS 1377, 1990, has the so-called "soft" base and is used much rarely. However, the results of research conducted in the Casagrande apparatuses of various types appear in the literature. In this article, the results obtained using the Casagrande device with hard and soft bases, have been analysed separately.

\section{RESULTS AND THEIR INTERPRETATION}

\section{GENERAL WL/CONE/WLICUP CORRELATION}

The liquid limit tests carried out on glacigenic soils of the North Polish Glaciation, deposited near Poznań in Poland, allow formulating the following correlation between the liquid limit value determined in the Casagrande apparatus $\left(\mathrm{w}_{\llcorner/ \text {cup }}\right)$ and in the cone penetrometer $\left(\mathrm{w}_{\mathrm{L} / \mathrm{cone}}\right)$ :

$$
\mathrm{W}_{\mathrm{L} / \text { cone }}=0.91 \mathrm{~W}_{\mathrm{L} / \text { cup }}+1.98 \quad\left[\mathrm{R}^{2}=0.997, \mathrm{n}=47\right]
$$



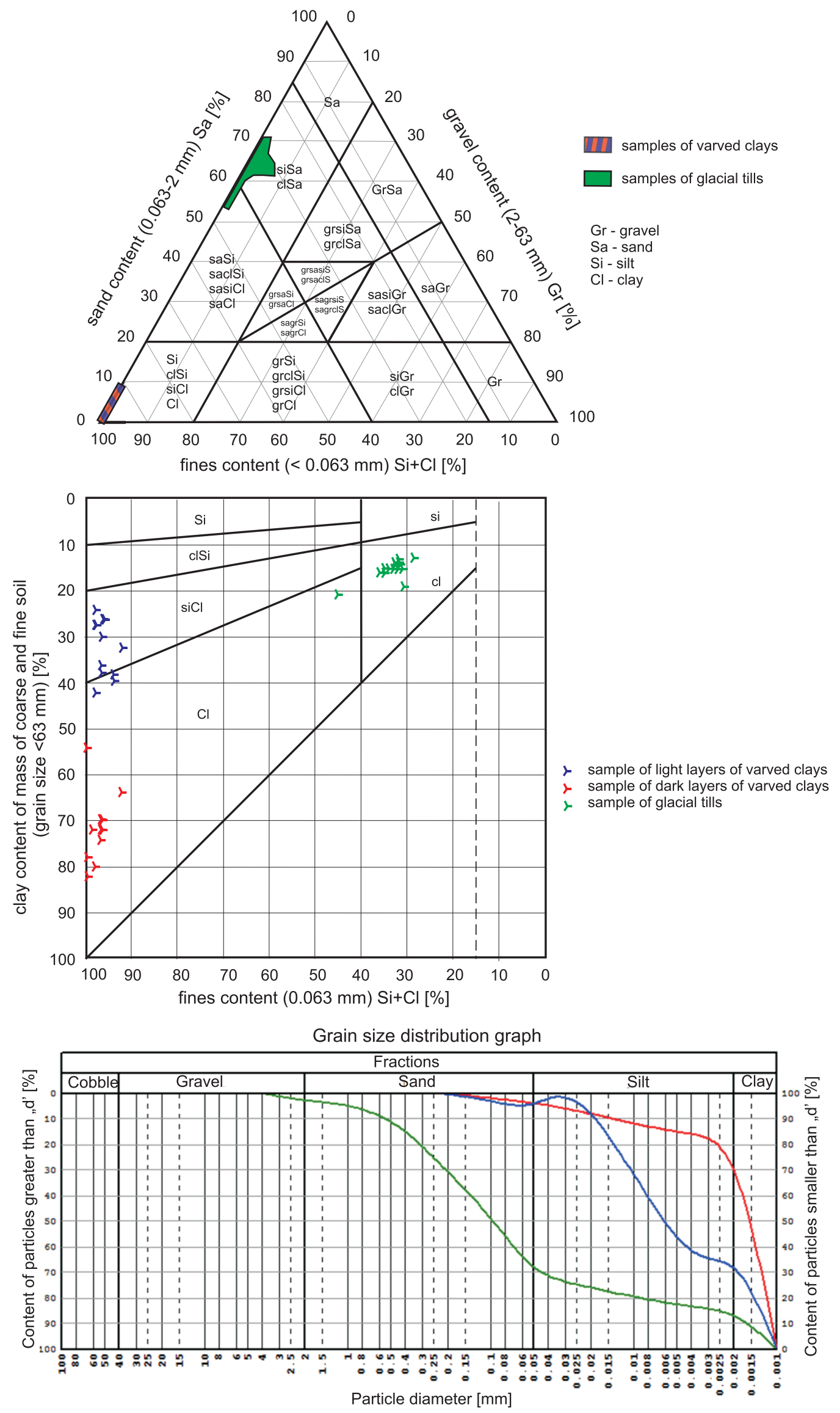

Fig. 3. Grain size composition of tested samples 

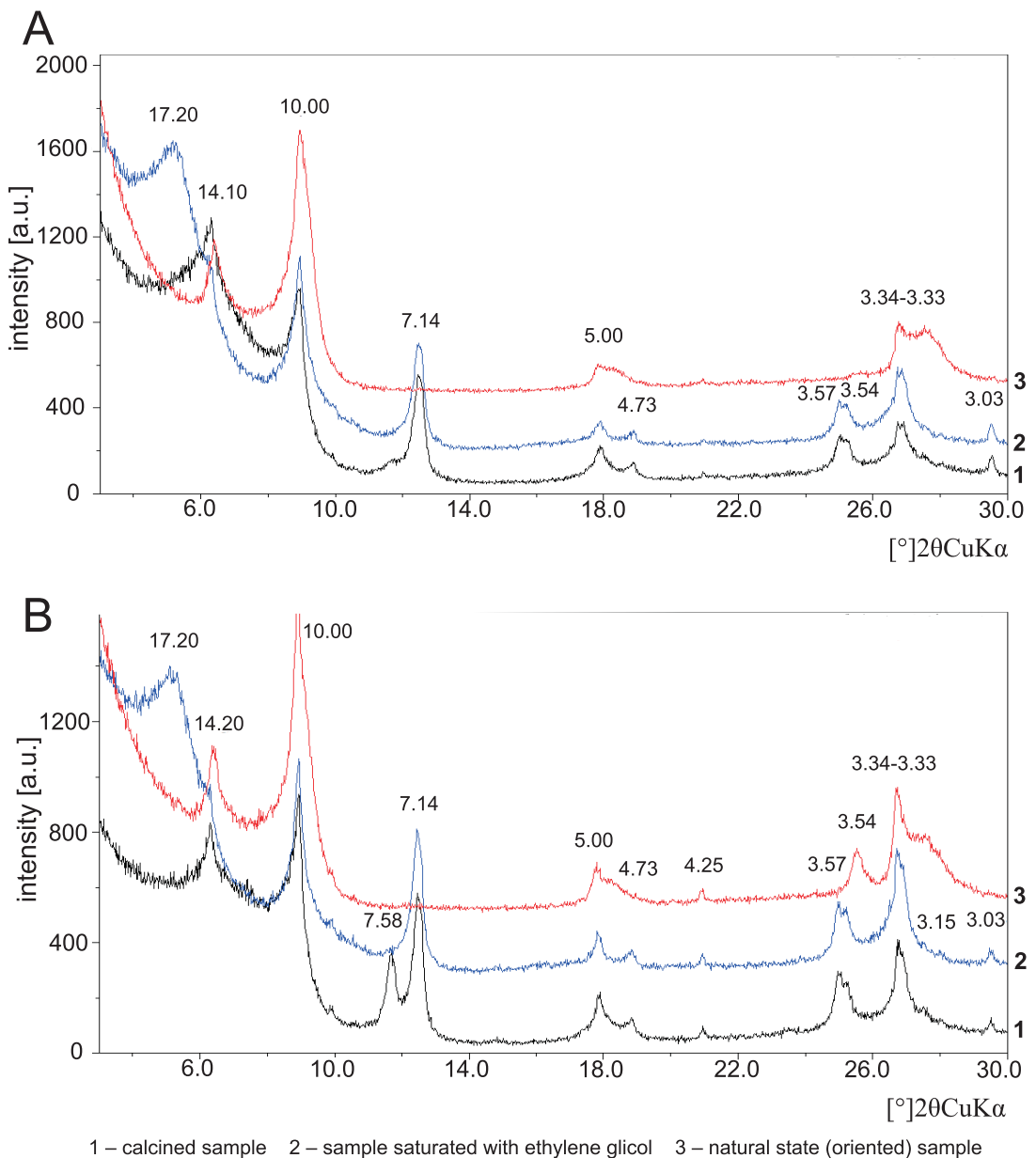

Fig. 4. X-ray diffraction patterns of selected samples of varved clays A - for the dark layer, B - for the light layer

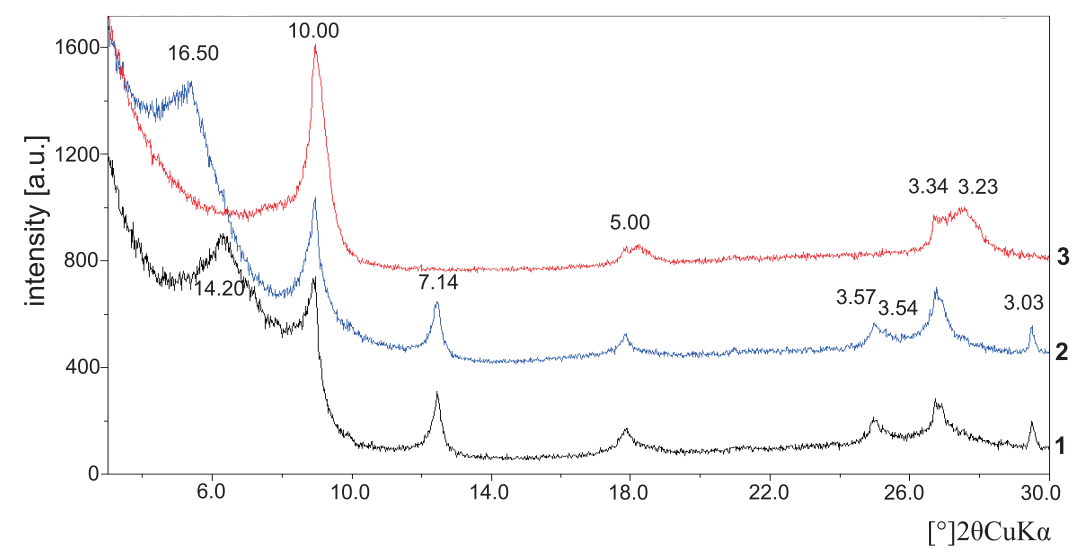

Fig. 5. X-ray diffraction pattern of a selected sample of ablational morainic tills 


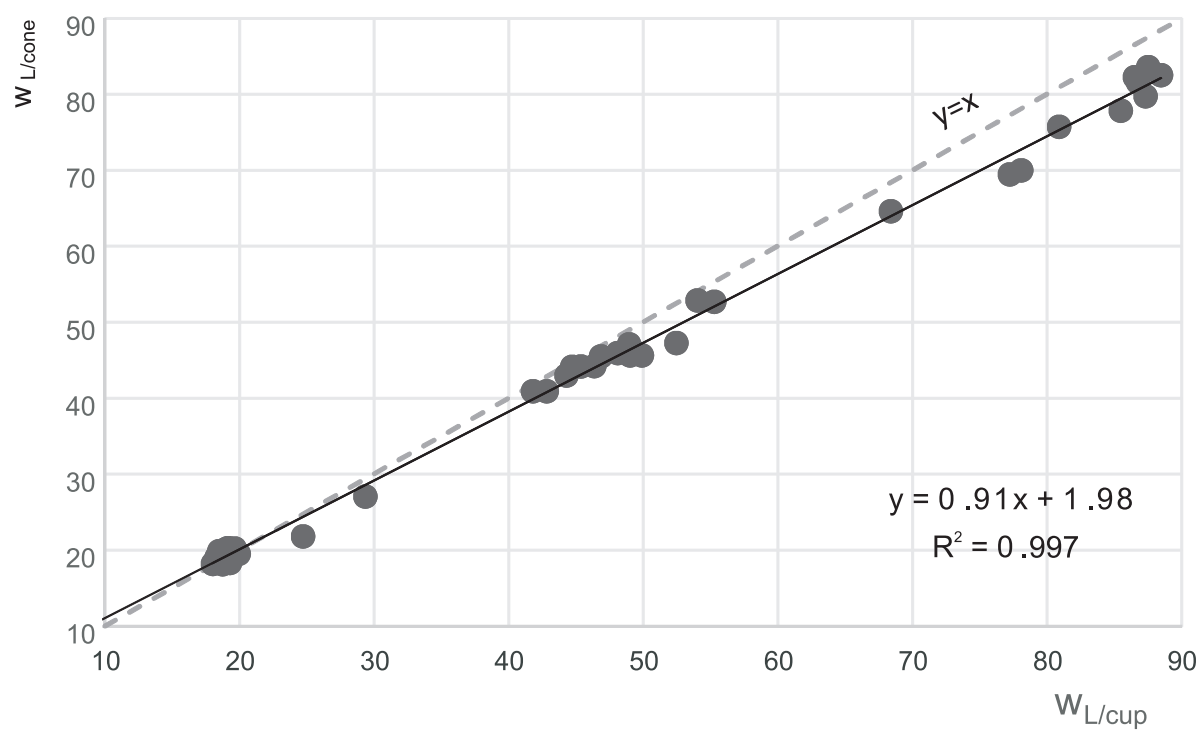

Fig. 6. The relationship between the liquid limit value determined in the Casagrande apparatus and in the cone penetrometer for the glacigenic soils of the North Polish Glaciation - varved clays and morainic tills

The relationship was determined experimentally for a relatively wide range of $W_{L}$ values (18-89\%) for natural soils of similar origins and occurrences.

The determination coefficient $\left(R^{2}\right)$, one of the basic measures of the quality of model fit, indicates what amount (in percentage) of one variable explains the variance of the second variable. For the equation [1] it is 0.997 (Fig. 6), so it falls in the so-called very good fit (Ziegel, 2004).

\section{THE W/CONE/W W/CUP $_{\text {CORRELATION FOR SOILS }}$ WITH LOW PLASTICITY}

In this research, an attempt was made to establish a relationship between the liquid limit values determined in the Casagrande apparatus and in the cone penetrometer for soils with low plasticity (slightly plastic soils). These are soils that contain a small admixture of clay fraction $(<20 \%)$, and thus have a low $W_{L}$ value (the minimum liquid limit value for North Polish glacial tills can even reach approximately $18 \%$ ).

In the literature, this type of research for soils with the low liquid limit value does not appear very often, e.g. $w_{L}=13-48 \%$ or $\mathrm{w}_{\mathrm{L}}=20-100 \%$. It was found that the $\mathrm{w}_{\mathrm{L} / \text { cone }} / \mathrm{w}_{\mathrm{L} / \text { cup }}$ correlation for soils with a low clay fraction content (in this case for medium plastic glacial tills, $\mathrm{w}_{\mathrm{L}}=18-30 \%$ ) is much less accurate than that for soils with higher plasticity (varved clays) (Fig. 7).

The $\mathrm{R}^{2}$ coefficient in the discussed correlation for the tills is 0.857 ; thus, it is definitely lower than that for the varved clays $\left(R^{2}=0.992\right)$ containing $26-84 \%$ clay fraction. This difference may be caused by the generally lower accuracy of determination of the liquid limit in soils with a low value of this parameter. Due to the high degree of heterogranularity (Fig. 3) of glacial tills, the soil paste prepared from them is usually less homogeneous than the varved clay paste. In addition, during the tests in low and medium plasticity soils, a problem with forming the smooth surface of the sample in the Casagrande apparatus cup and in the probe of the cone penetrometer may occur, espe- cially at the lower moisture content of the soil paste. This fact may affect the accuracy of the test results. It is recommended to conduct a larger number of analyses for soils with the $W_{L}$ value $<30 \%$ in order to clarify the relationship between the liquid limit value determined in the Casagrande apparatus and in the cone penetrometer.

\section{THE POINT OF EQUIVALENT RESULTS}

Based on the tested soil paste samples, it was found that the liquid limit value obtained in the Casagrande apparatus for the soils with $w_{L}>22 \%$ was slightly higher (by $\sim 5.5 \%$ ) than that obtained in the cone penetrometer. However, if the $w_{L}$ value does not exceed $22 \%$, then the test results in the cone penetrometer are slightly overestimated (by $\sim 3.5 \%$ ) (Fig. 6).

Similar observations of a certain level of the liquid limit value above which the Casagrande apparatus gives higher $\mathrm{W}_{\mathrm{L}}$ values were made by many authors, most of which are cited in this paper (Table 1). For the purposes of this study, this level is called "the point of equivalent results" ( $\left.\mathrm{w}_{\mathrm{L} / \text { cone }}=\mathrm{w}_{\mathrm{L} / \mathrm{cup}}\right)$. The point of equivalent results in the plots of the $\mathrm{W}_{\mathrm{L} / \text { cup }} / \mathrm{w}_{\mathrm{L} / \text { cone }}$ relationship is the intersection point of the given line with the function $y=x$ (Fig. 6). Based on the research results published by various authors (Table 1), a divergence in $\mathrm{w}_{\mathrm{L} / \text { cone }}=\mathrm{w}_{\mathrm{L} / \text { cup }}$ from approximately 16 to $188 \% W_{L}$ can be found (Table 2 ). The value of $22 \%$ determined in this work for Polish postglacial soils is in the lower part of this range. The position of the point $\mathrm{w}_{\mathrm{L} / \text { cone }}=\mathrm{W}_{\mathrm{L} / \text { cup }}$ was determined based on the cited studies in two ways. If the $\mathrm{W}_{\mathrm{L} / \mathrm{cone}}$ $=\mathrm{W}_{\mathrm{L} / \mathrm{cup}}$ value was within the range of the liquid limit values of the tested samples, then it was considered that the point of equivalent results was determined "experimentally". If, however, the point of equivalent results was not in this range (i.e. it was not determined experimentally) then, using the formula of the function $\mathrm{W}_{\mathrm{L} / \text { cup }} / \mathrm{W}_{\mathrm{L} / \text { cone }}$, the graph was extended to the intersection with the $x=y$ line and $w_{L / c o n e}=w_{L / c u p}$ was read "theoretically" (Table 2). 

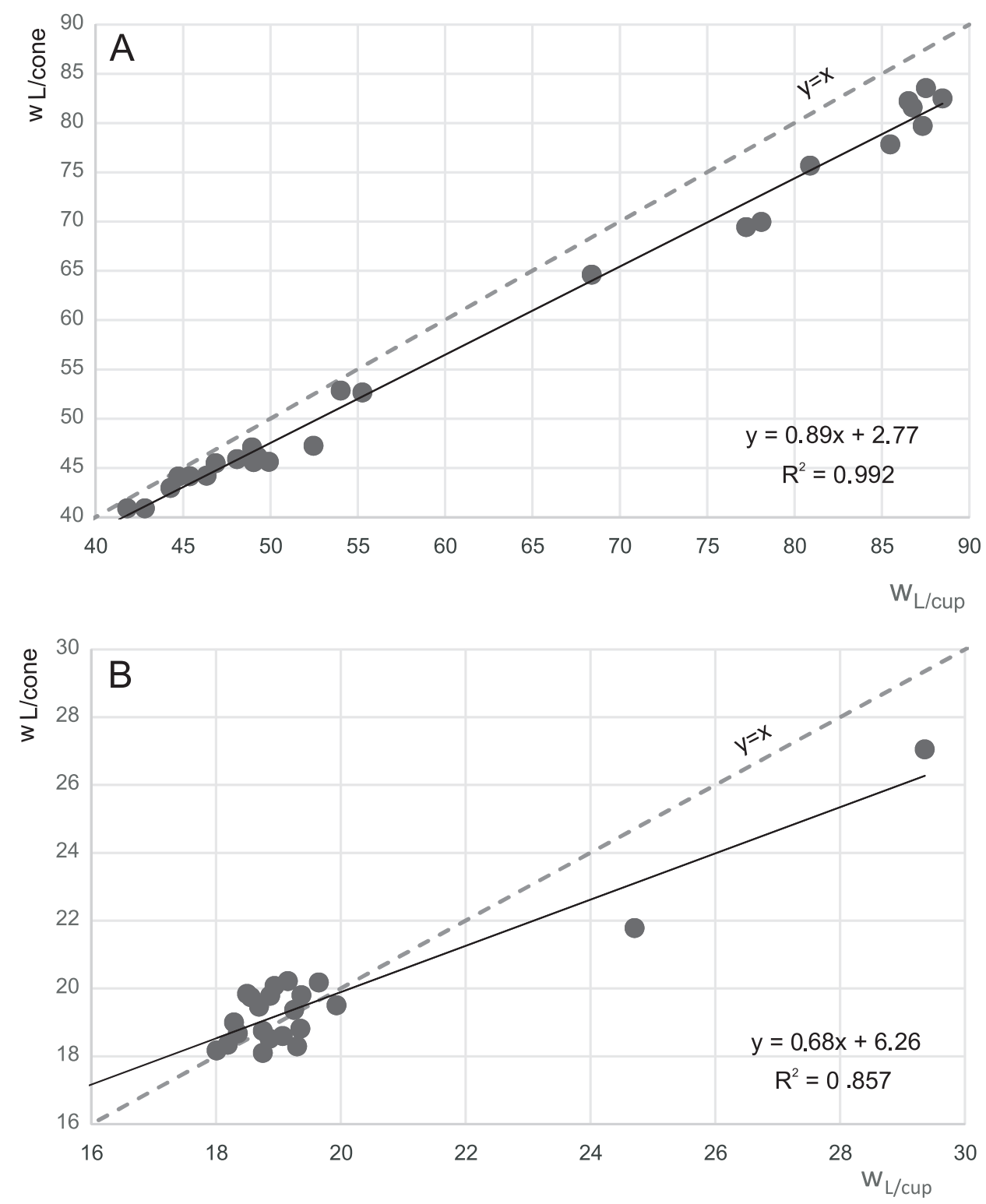

Fig. 7. The relationship between the liquid limit value in the Casagrande apparatus and in the cone penetrometer as determined separately for: A - varved clays, B - glacial tills

\section{COMPARISON WITH PREVIOUSLY PUBLISHED RESULTS}

Of 19 relationships published in the literature (Table 1), 12 tend to be similar to the correlation derived in the current article (Table 2), and the remaining seven differ noticeably. Seven of the authors suggested that the liquid limit value determined in the cone penetrometer is always greater than that determined in the Casagrande apparatus (Sampson and Netterberg, 1985; Wasti and Bezirci, 1986; Queiroz de Carvalho, 1986; Orhan et al., 2006; Dragoni et al., 2008; Fojtová et al., 2009; Di Matteo, 2012), and 12 of them claim that, in the higher range of the $w_{L}$ value (above the point of equivalent results), the Casagrande apparatus gives higher $W_{L}$ values than the cone penetrometer (Wires, 1984; Belviso et al., 1985; Budhu, 1985; Leroueil and Le Bihan, 1996; Sridharan et al., 1999; Özer, 2009; Grønbech et al., 2011; Spagnoli, 2012).
Among the published correlations, one of the closest to that proposed in this study is the relationship of $\mathrm{W}_{\mathrm{L} / \text { cone }}=0.86 \mathrm{~W}_{\mathrm{L} / \text { cup }}+$ 6.34 derived by Leroueil and Le Bihan (1996) (Table 2). This correlation was developed for marine silty clays and lacustrine varved clays of eastern Canada with the $\mathrm{w}_{\mathrm{L}}$ values in the range of 30-74\%. Similar correlations are also reported by Wires (1984), Belviso et al. (1985) and Özer (2009) (Fig. 2). However, the origins of the soils analysed in those studies were not provided.

One of the relationships particularly different from Equation [1], derived on the basis of research presented in this article, is $\mathrm{W}_{\mathrm{L} / \text { cone }}=1.07 \mathrm{w}_{\mathrm{L} / \text { cup }}+2.18$ proposed by Queiroz de Carvalho (1986). Such a difference suggests that the $W_{L}$ value is significantly higher in the case of testing in a cone penetrometer. The difference according to the aforementioned correlation is about $3.5 \%$ for cohesive soils with a liquid limit of $20 \%$. This difference increases with the increase in the $\mathrm{w}_{\mathrm{L}}$ value (to $\sim 6 \%$ with $\mathrm{w}_{\mathrm{L}}=$ $50 \%$ ). This correlation was created on the basis of research on cohesive soils that were formed as saprolite (laterite soils) origi- 
Table 2

The value of the point of equivalences of results $\left(\mathrm{w}_{\mathrm{L} / \mathrm{cone}}=\mathrm{w}_{\mathrm{L} / \mathrm{cup}}\right.$ ) according to different authors (ascending)

\begin{tabular}{|c|c|c|c|c|c|}
\hline No. & Author, year & \multicolumn{2}{|c|}{$\begin{array}{l}\text { The point of equivalent of results } \\
\left.\text { ( } \mathrm{W}_{\mathrm{L} / \text { cone }=\text { cup }}\right)\end{array}$} & $\begin{array}{l}\text { The } w_{L}[\%] \text { range } \\
\text { of research }\end{array}$ & $\begin{array}{l}\text { The way of finding } \\
\qquad W_{L / \text { cone }=\text { cup }}\end{array}$ \\
\hline 1 & Wires (1984) & 16.17 & when $w_{L}>16 \% w_{L / c u p}>w_{L / c o n e}$ & $32-52$ & theoretically \\
\hline 2 & $\begin{array}{c}\text { Sherwood and Ryley } \\
(1970)\end{array}$ & 19.00 & when $\mathrm{w}_{\mathrm{L}}>19 \% \mathrm{w}_{\mathrm{L} / \text { cup }}>\mathrm{w}_{\mathrm{L} / \text { cone }}$ & $30-72$ & theoretically \\
\hline 3 & Present study & 22.00 & when $\mathrm{w}_{\mathrm{L}}>22 \% \mathrm{w}_{\mathrm{L} / \text { cup }}>\mathrm{W}_{\mathrm{L} / \text { cone }}$ & 18-89 & experimentally \\
\hline 4 & Karlsson $(1961,1977)$ & 33.47 & when $\mathrm{w}_{\mathrm{L}}>33 \% \mathrm{w}_{\mathrm{L} / \text { cup }}>\mathrm{w}_{\mathrm{L} / \text { cone }}$ & $30-76$ & experimentally \\
\hline 5 & Belviso et al. (1985) & 39.67 & when $\mathrm{w}_{\mathrm{L}}>40 \% \mathrm{w}_{\mathrm{L} / \text { cup }}>\mathrm{W}_{\mathrm{L} / \text { cone }}$ & $34-134$ & experimentally \\
\hline 6 & Leroueil, Le Bihan (1996) & 45.29 & when $\mathrm{w}_{\mathrm{L}}>45 \% \mathrm{w}_{\mathrm{L} / \text { cup }}>\mathrm{w}_{\mathrm{L} / \text { cone }}$ & $30-74$ & experimentally \\
\hline 7 & Littleton, Farmilo (1977) & 53.33 & when $\mathrm{w}_{\mathrm{L}}>53 \% \mathrm{w}_{\mathrm{L} / \text { cup }}>\mathrm{w}_{\mathrm{L} / \text { cone }}$ & no data & no data \\
\hline 8 & Sridharan, Prakash (2000) & 55.28 & when $\mathrm{w}_{\mathrm{L}}>55 \% \mathrm{w}_{\mathrm{L} / \text { cup }}>\mathrm{w}_{\mathrm{L} / \text { cone }}$ & $32-92$ & experimentally \\
\hline 9 & Özer (2009) & 60.40 & when $\mathrm{w}_{\mathrm{L}}>60 \% \mathrm{w}_{\mathrm{L} / \text { cup }}>\mathrm{W}_{\mathrm{L} / \text { cone }}$ & 29-104 & experimentally \\
\hline 10 & Budhu (1985) & 61.43 & when $\mathrm{w}_{\mathrm{L}}>61 \% \mathrm{w}_{\mathrm{L} / \text { cup }}>\mathrm{W}_{\mathrm{L} / \text { cone }}$ & $20-100$ & experimentally \\
\hline 11 & Sridharan et al. (1999) & 63.53 & when $\mathrm{w}_{\mathrm{L}}>64 \% \mathrm{w}_{\mathrm{L} / \text { cup }}>\mathrm{w}_{\mathrm{L} / \text { cone }}$ & $29-92$ & experimentally \\
\hline 12 & Spagnoli (2012) & 105.00 & when $\mathrm{w}_{\mathrm{L}}>105 \% \mathrm{~W}_{\mathrm{L} / \text { cup }}>\mathrm{W}_{\mathrm{L} / \text { cone }}$ & $28-61$ & theoretically \\
\hline 13 & Grønbech et al. (2011) & 188.00 & when $\mathrm{W}_{\mathrm{L}}>188 \% \mathrm{~W}_{\mathrm{L} / \text { cup }}>\mathrm{W}_{\mathrm{L} / \text { cone }}$ & $100-340$ & experimentally \\
\hline
\end{tabular}

nating from northern and northeaster Brazil. The difference in the research results mentioned above can therefore be caused by a distinctly different genesis of land.

In 2012, Di Matteo attempted to create a universal $\mathrm{w}_{\mathrm{L} / \text { cup }} / \mathrm{w}_{\mathrm{L} / \text { cone }}$ correlation. For this purpose, he used the results of tests published earlier by various authors (100 samples of soils of different origins). In this way, the relationship $\mathrm{w}_{\mathrm{L} / \mathrm{cone}}=$ $1.00 \mathrm{w}_{\mathrm{L} / \mathrm{cup}}+2.20$ was derived. It was determined, however, in a fairly narrow range of the liquid limit value (24-40\%) and suggests that the cone penetrometer always overestimates slightly the results obtained from the Casagrande apparatus (Table 1). The conclusions from these considerations do not coincide with the results obtained for Polish postglacial deposits, because, as previously stated, the liquid limit value of the discussed soils determined in the Casagrande apparatus is usually slightly above $22 \%$.

\section{CONCLUSIONS}

The purpose of research presented in this article was to determine the liquid limit values of cohesive soils using various laboratory methods. Soils with a wide range of clay fraction content were tested. The ages, origins and occurrences of these soils were similar. All tested samples were glacial soils from the youngest glaciation in western Poland. Based on the research results and their comparison with the existing literature the following conclusions can be drawn:

- It is difficult to derive a generalized and universal relationship between the liquid limit value determined in the Casagrande apparatus ( $\mathrm{w}_{\mathrm{L} / \mathrm{cup}}$ ) and in the cone penetrometer ( $\left.W_{L / \text { cone }}\right)$.
- However, such correlations can be determined for soils of similar genesis and similar mineral composition, e.g. sediments of the youngest glaciation in the northern hemisphere.

- In order to compare the $\mathrm{w}_{\mathrm{L} / \text { cup }}$ and $\mathrm{w}_{\mathrm{L} / \text { cone }}$ values, the linear function (Equation 1) can be used for the glacigenic soils of the youngest glaciation (glacial tills and varved clays) deposited in the Polish Lowlands.

- Equation [1] can be used as the amendment for developing compilations of the liquid limit values or other geotechnical parameters determined on its basis by the indirect method for the aforementioned soils. If the results in these compilations come from contemporary and archival laboratory tests it is necessary to check which method the liquid limit was determined with and, if necessary, correct it according to Equation [1].

- Future research on determining the liquid limit of natural soils in low ranges of this parameter $\left(w_{L}<30 \%\right)$ should be intensified.

- The specific liquid limit value above which the Casagrande apparatus gives higher $\mathrm{w}_{\mathrm{L}}$ values can be determined. For the purposes of this study, this value was called "the point of equivalent results" ( $\left.\mathrm{w}_{\mathrm{L} / \mathrm{cone}}=\mathrm{w}_{\mathrm{L} / \mathrm{cup}}\right)$. For Polish postglacial soils examined in this paper the value of $\mathrm{W}_{L / \text { cone }}=\mathrm{W}_{\mathrm{L} / \text { cup }}$ is $22 \%$.

It is advised to standardize the method used to determine the liquid limit. Following the recommendation given in Eurocode 7 , using the cone penetrometer, in both scientific and commercial laboratories, would be a good engineering practice.

Acknowledgements. The authors would like to thank the Reviewers for their constructive comments and appreciation to our work. 


\section{REFERENCES}

ASTM D 4318, 2000. "Standard test methods for liquid limit, plastic limit and plasticity index of soils". Annual Book of American Society for Testing and Material Standards.

Atterberg, A., 1911. Die plastizität der Tone. Internationale Mitteilungen Bodenkunde, 1: 4-37.

Atterberg, A., 1912. Die Konsistenz und die Bindigheit der Boden. Internationale Mitteilungen Bodenkunde, 2: 148-189.

Belviso, R., Ciampoli, S., Cotecchia, V., Federico, A., 1985. Use of the cone penetrometer to determine consistency limits. Ground Engineering, 18: 39-47.

BS 1377, 1990. "Methods of test for soils for civil engineering purposes". BSI - British Standards Institution.

Budhu, M., 1985. The effect of clay content on liquid limit from a fall cone and the British cup device. Geotechnical Testing Journal, 8: 91-95.

Casagrande, A., 1932. Research on the Atterberg limits of soils. Public Roads, 13: 121-136.

Christaras, B., 1991. A comparison of the Casagrande and fall cone penetrometer methods for liquid limit determination in marls from Crete, Greece. Engineering Geology, 31: 131-142.

ČSN 721014, 1968. "Laboratorni stanoveni meze tekutosti zemin" (in Czech). Česka Agentura pro Standadizaci.

Di Matteo, L., 2012. Liquid limit of low- to medium-plasticity soils: comparison between Casagrande cup and cone penetrometer test. Bulletin of Engineering Geology and the Environment, 71: 79-85.

DIN 18122, 2008. "Erkundung und Untersuchung des Baugrunds". Beuth Verlag.

Dragoni, W., Prosperini, N., Vinti, G., 2008. Some observations on the procedures for the determination of the liquid limit: an application on Plio-Pleistocenic clayey soils from Umbria region (Italy). Italian Journal of Engineering Geology and Environment, 1(2008): 185-197.

Flieger-Szymańska, M., Machowiak, K., 2010. Wstępne dane na temat zróżnicowania składu granulometrycznego iłów warwowych w dorzeczu strumienia junikowskiego w południowo-zachodniej części Poznania (in Polish). Archiwum Instytutu Inżynierii Lądowej Politechniki Poznańskiej, 7: 45-53.

Florkiewicz, A., Flieger-Szymańska, M., Machowiak, K., Wanatowski, D., 2015. Engineering properties of varved clays from the Junikowski Stream valley in Poland. Geotechnics for Catastrophic Flooding Events: 267-273.

Fojtová, L., Marschalko, M., Franeková, R., Kovár, L., 2009. Study of compatibility of methods for liquid limit measurement according to Czech State Standard and newly adopted European Standard. Geoscience Engineering, 55: 55-68.

Grønbech, G.L., Nielsen, B.N., Ibsen, L.B., 2011. Comparison of liquid limit of highly plastic clay by means of Casagrande and Fall Cone Apparatus. Pan-Am CGS Geotechnical Conference, 40-46.

Hanks, A.J., 1981. Measurement of the liquid limit of soils using the cone penetration method. Ontario Ministry of Transportation and Communication, Engineering Materials Office, Soils and Aggregates Section, Toronto.

Hrubesova, E., Lunackova, B., Brodzki, O., 2016. Comparison of liquid limit of soils resulted from Casagrande test and modificated cone penetrometer methodology. Procedia Engineering, 142: 364-370.

Jaśkiewicz, K., Wszędyrówny-Nast, M., 2013. Wpływ metodyki oznaczania granic Atterberga na uzyskiwane wartości stopnia plastyczności (in Polish). Budownictwo i Inżynieria Środowiska, 4: 113-118.

Leroueil, S., and Le Bihan, J.P., 1996. Liquid limits and fall cones. Canadian Geotechnical Journal, 33: 793-798.

Norman, L.E.J., 1958. A comparison of values of liquid limit determined with apparatus having bases of different hardness. Geotechnique, 8: 79-83.

Orhan, M., Ozer, M., Isik, N., 2006. Comparison of Casagrande and cone penetration tests for the determination of liquid limit of natural soils. Journal of the Faculty of Engineering and Architecture of Gazi University, 21: 711-720.

Özer, M., 2009. Comparison of liquid limit values determined using the hard and soft base Casagrande apparatus and the cone penetrometer. Bulletin of Engineering Geology and the Environment, 68: 289-296.

PKN-CEN ISO/TS 17892-1, 2009. „Badania geotechniczne. Badania laboratoryjne gruntów. Część 1: Oznaczanie wilgotności" (in Polish). Polski Komitet Normalizacyjny.

PKN-CEN ISO/TS 17892-4, 2009. „Badania geotechniczne. Badania laboratoryjne gruntów. Część 4: Oznaczanie składu granulometrycznego" (in Polish). Polski Komitet Normalizacyjny.

PKN-CEN ISO/TS 17892-12, 2009. „Badania geotechniczne. Badania laboratoryjne gruntów. Część 12: Oznaczanie granic Atterberga" (in Polish). Polski Komitet Normalizacyjny.

PN-88/B-04481, 1988. „Grunty budowlane. Badania próbek gruntu” (in Polish). Polski Komitet Normalizacji, Miar i Jakości.

PN-EN 1997-1/2 Eurokod 7, 2008/2009. „Projektowanie geotechniczne" (in Polish). Polski Komitet Normalizacyjny.

Queiroz de Carvalho, J., 1986. The applicability of the cone penetrometer to determine the liquid limit of lateritic soils. Geotechnique, 36: 109-111.

Sampson, L., Netterberg, F., 1985. The cone penetration index: a simple new soil index test to replace the plasticity index. Proceedings of 11 th international conference on soil mechanics and foundation engineering: 1041-1048.

Sowers, G., Vesić, A., Grandolfi, M., 1960. Penetration tests for liquid limit. Papers on Soils 1959 Meetings. ASTM International.

Spagnoli, G., 2012. Comparison between Casagrande and drop-cone methods to calculate liquid limit for pure clay. Canadian Journal of Soil Science, 92: 859-864.

Sridharan, A., Nagaraj, H.B., Prakash, K., 1999. Determination of the plasticity index from flow index. Geotechnical Testing Journal, 22: 175-181.

Suchnicka, H., 1999. Znaczenie sposobu oceny granicy płynności w identyfikacji stanu gruntu spoistego (in Polish). Inżynieria i Budownictwo, 55: 449-451.

Wasti, Y., 1987. Liquid and plastic limits as determined from the fall cone and the Casagrande methods. Geotechnical Testing Journal, 10: 26-30.

Wasti, Y., Bezirci, M., 1986. Determination of the consistency limits of soils by the fall cone test. Canadian Geotechnical Journal, 23: $241-246$.

Wires, K., 1984. The Casagrande method versus the drop-cone penetrometer method for the determination of liquid limit. Canadian Journal of Soil Science, 64: 297-300.

Ziegel, E.R., 2004. The Oxford dictionary of statistical terms. Technometrics, 46: 266-26. 